\title{
Vegetation distribution along a granite catena, southern Kruger National Park, South Africa
}

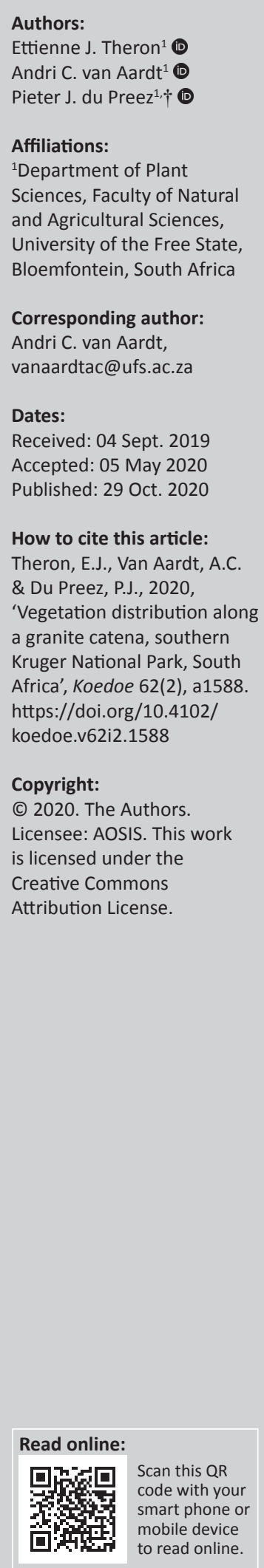

This study aimed to investigate how environmental factors drive the assemblage of vegetation within a landscape at various scales, particularly to which extent a sequence of soil forms (catena) influences plant community distribution in a savanna of Kruger National Park, South Africa. On a regional scale, the geology and associated soil forms correspond to the Granite Lowveld Vegetation Type. These associations were studied at the scale of a single hillslope, comprising concurrent soil and vegetation surveys from the crest to footslopes. From chemical and physical soil analyses, strong correlations between the distribution of soil moisture content, soil forms and plant species at community, sub-community and variant levels were found. A Vachellia exuvialis-Pogonarthria squarrosa-dominated savanna is restricted to the well-drained, nutrient-poor, acidic and sandy soils of the crests and upper-midslopes of the granite domes. On sodic sites along lower-midslopes, Dactyloctenium aegyptium-Sporobolus nitens grasslands dominate the clay-rich soils. The footslopes are characterised by the grass Themeda triandra and the shrub Flueggea virosa. The grass Panicum maximum growing under tall trees such as Diospyros mespiliformis and Spirostachys africana typifies riparian vegetation along seasonal streams on deep alluvial soil. The association between plant communities and soil forms exemplifies the interdependency of biotic and abiotic components that maintain heterogeneity within the ecosystem from biome to community scale.

Conservation implications: This article contributes to understanding plant species distribution along a granite catena; an integral part of which are sodic sites that become overutilized by game, which, albeit natural, could severely impact these sites during drought situations.

Keywords: Vegetation classification; Vegetation ordination; Catenas; Sodic sites; Soil factors; Environmental gradient.

\section{Introduction}

Vegetation forms an integral part of any ecosystem and can only be fully studied when the role it plays in the ecosystem is explored (Kent 2012). Identification of vegetation types and plant communities that provide a habitat for animals, insects and birds is, in turn, associated with certain environmental controls and human or animal interactions. Understanding the interaction that vegetation has with environmental factors can lead to improved monitoring of management practices and possibly predict future changes (Kent 2012).

In Kruger National Park (KNP), several vegetation studies were conducted over the past 60 years. However, most were focused on areas where environmental conditions such as fire and herbivory were manipulated. Smit et al. (2013) noted that research on areas under natural conditions and where the geology and rainfall vary should be a priority. They identified four supersites that represent the typical rainfall gradient and geological contrast of KNP.

One of these sites is the Stevenson-Hamilton Research Supersite where this study on a catena took place. Brady and Weil (2002) define a catena as a soil sequence in which each particular soil group occurs on the same parent material, but in different arrays from foothills to crest zones. The study site with its undulating landscape is known to occur on granite, which shows a prevalence of fine- to coarse-grained biotite (Schutte 1974) (Figure 1) and expresses a general soil sequence where sand and clay content are inversely proportional. The catena includes sandy soils that dominate crest zones, clayey soils that are prevalent on midslopes and alluvial sand in the riparian corridors. The soil properties of both sand and clay affect hillslope hydrology and

Note: Additional supporting information may be found in the online version of this article. Online Appendix 1.

Note: Special Issue: Connections between abiotic and biotic components of a granite catena ecosystem in Kruger National Park, sub-edited by Beanelri Janecke and Johan van Tol. $\dagger, 1960-2019$. 
subsequently also vegetation distribution and species composition (Venter, Scholes \& Eckhardt 2003).

In the southern granite regions of KNP, catenas can include well, moderately or poorly drained soil forms, depending on the relief. This facilitates the transfer of solutes, colloids or other particles from upslope areas downhill along an environmental gradient, resulting in soil differentiation (Conacher \& Dalrymple 1977; Huggett 2007; Khomo et al. 2011). Khomo et al. (2011) further state that crest soils act as a source of clay particles and ions for downslope areas and can become leached during this process. Furthermore, differences in elevation, combined with differences in the water flow pattern in a landscape, can result in soluble salts being transported from higher to lower lying areas. When the salt solute reaches an impermeable clay barrier at the mid- or footslopes, it can cause surface seepage which eventually evaporates (Brady \& Weil 2002). Because salt is not lost through evaporation, it may accumulate in certain areas where rainfall is insufficient to facilitate leaching. In areas with a semi-arid climate, such as the Skukuza region, KNP, the above-mentioned process often results in the formation of sodic sites on the lower ends of granitic catenas (Khomo \& Rogers 2005). Sodic sites are characterised by the hyperaccumulation of exchangeable sodium $(\mathrm{Na})$, which impacts the infiltration and flow of water within the affected soils (Khomo \& Rogers 2005; Naidu \& Rengasamy 1993).

In the studied part of the park, specific plant communities are associated with lowland sites and elevated clay and colloidal particle content in sodic soils. In addition to these factors, the hyper-accumulation of sodium along with other solutes promotes the establishment of salt-tolerant species. The vegetation structure is typified by short grasses and a lack of trees, fringed by low-growing shrubs. However, the increased nutritional quality and resistance to grazing of the grass sward often leads to over-utilisation by grazers (McNaughton 1988; Moxley 2013). Intense grazing or extreme accumulation of salts may indirectly result in the ultimate denudation of a sodic site's vegetation (Khomo \& Rogers 2005). This apparent degradation of an area would appear to warrant restoration or rehabilitation efforts. However, Khomo and Rogers (2005) argue that a holistic understanding of the ecology of sodic sites will contribute to improved management thereof, which is essential in a preserved area such as KNP.

Several research papers (Smit et al. 2013; Van Tol et al. 2015; Van Zijl \& Le Roux 2014) indicated that the sandy crests are dominated by Combretum apiculatum and Combretum zeyhri, the seeplines by Terminalia sericea, the clayey midslopes by Vachellia nilotica and the footslopes by Euclea divinorium. We investigated the community composition of the different terrain types along the catena aiming to provide a baseline vegetation description and its association with the different soil forms. This forms part of a multidisciplinary study investigating the interactions between biotic and abiotic components along a catena or hillslope in the area.

\section{Study area}

From a geological perspective, KNP can be divided lengthwise into eastern basaltic formations and western granitoid formations; the latter constituting roughly $60 \%$ of the park's surface (Barton, Bristow \& Venter 1986). The study area in the Stevenson-Hamilton Research Supersite (Figure 1) forms part of the Nelspruit Suite and consists of Archaean granite and gneiss (Alard 2009; Smit et al. 2013; Van Zijl \& Le Roux 2014). It is located at $25.111^{\circ} \mathrm{S}$ and $31.579^{\circ} \mathrm{E}$, about $7 \mathrm{~km}$ south of Skukuza (Bredenkamp 1982; McCarthy \& Rubidge 2005; Venter et al. 2003). The prevalence of the granite and gneiss parent material in the undulating landscapes results in shallow, nutrient-poor soils that vary from grey to red to brown in colour (Venter et al. 2003).

The Stevenson-Hamilton Research Supersite forms part of the Granite Lowveld (SVI3) vegetation type that belongs to the Savanna Biome, which constitutes a large portion of South Africa's vegetation (eds. Mucina \& Rutherford 2006). This vegetation type is characterised by a ground layer dominated by tall grass swards with intermittent trees or other woody species (Naidoo et al. 2012; Rutherford \& Westfall 1986).

The semi-arid regional climate falls within a summer seasonal rainfall regime, with an average annual precipitation of $650 \mathrm{~mm}$ that ranges from a maximum of $1000 \mathrm{~mm}$ to as little as $235 \mathrm{~mm}$ per annum (Naidoo et al. 2012; Smit et al. 2013)

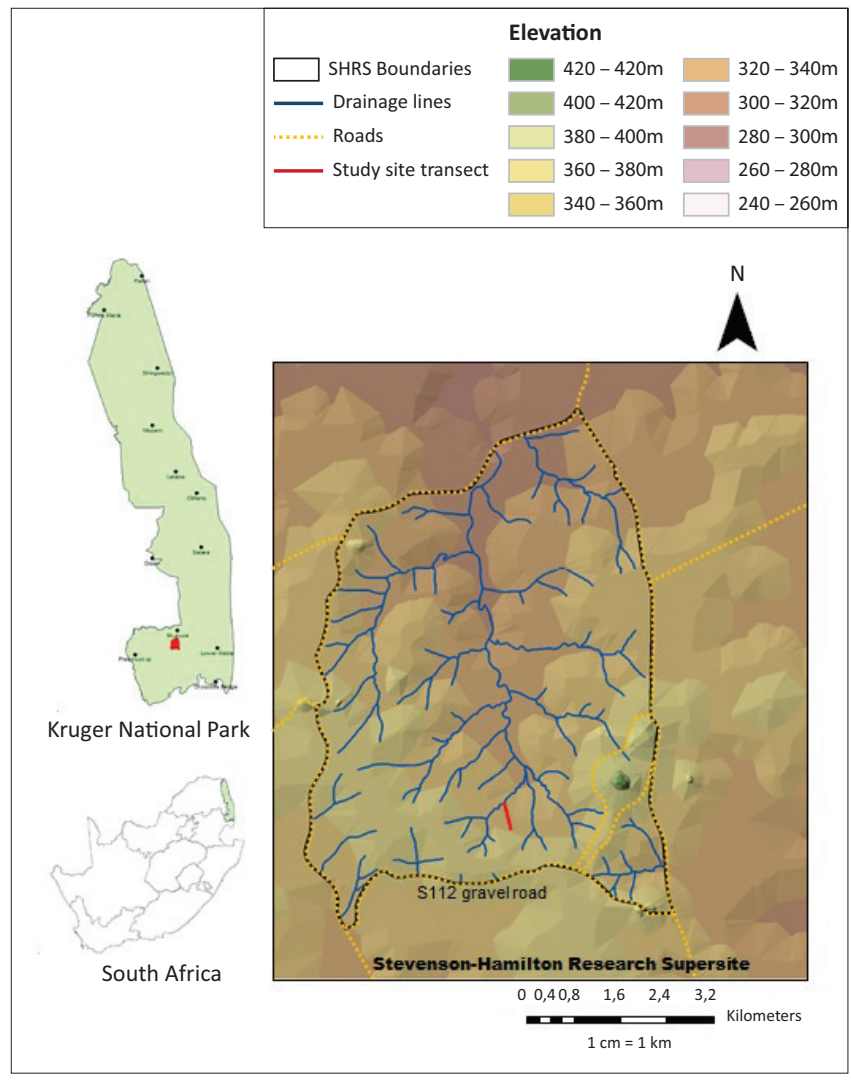

FIGURE 1: Location and elevation (meter above mean sea level) of the study site within Stevenson-Hamilton Research Supersite (SHRS), Kruger National Park, South Africa. 
falling mostly during December and January (Kruger, Makamo \& Shongwe 2002). Skukuza and its surroundings have a mean annual air temperature of $21^{\circ} \mathrm{C}-22^{\circ} \mathrm{C}$ (Khomo et al. 2011; Scholes, Bond \& Eckhardt 2003), and the seasonal and diurnal temperature fluctuations were shown by Kruger et al. (2002) to be largely statistically insignificant, except in the month of March. However, extreme periods of both inundation and aridity are known to occur.

\section{Methods \\ Data collection}

To measure marked changes in vegetation and spatial environmental gradients, 49 plots of $10 \mathrm{~m}^{2}$ were laid out next to each other to form a $490 \mathrm{~m}$ long (straight) belt transect across the study area (Brown et al. 2013; Kent 2012). The transect stretched from the crest of the hillslope and included plots within the midslope, the ecotone between the midslope and sodic site, the sodic site itself, the ecotone between the sodic site and the riparian area and, finally, the riparian area. This was the only transect where soil moisture and groundwater data were available to aid in the creation of a hydrological soil response map of the study area (Figure 2) (Van Zijl \& Le Roux 2014). However, soil moisture probes were damaged by wildlife during the course of study, rendering the data unavailable for use in the interpretation of the vegetation analysis. The cover abundance of 172 plant species was recorded by means of the modified Braun-Blanquet cover abundance scale (Kent 2012; Kent \& Coker 1992; Van der Maarel \& Franklin 2013), which grouped the vegetation in eight categories based on the percentage of ground cover each constituted, respectively (Table 1). In selected plots, the vegetation cover was low, and areas of exposed soil were visible. The cover abundance of these exposed areas was recorded as a pseudo-species, indicated as 'Bare soil'.

A soil sample was collected in the middle of each $10 \mathrm{~m}^{2}$ plot laid out along the hillslope from the crest to the drainage line. Within each of the 49 sample plots, soil was collected by means of a bucket soil auger to determine the soil depth.

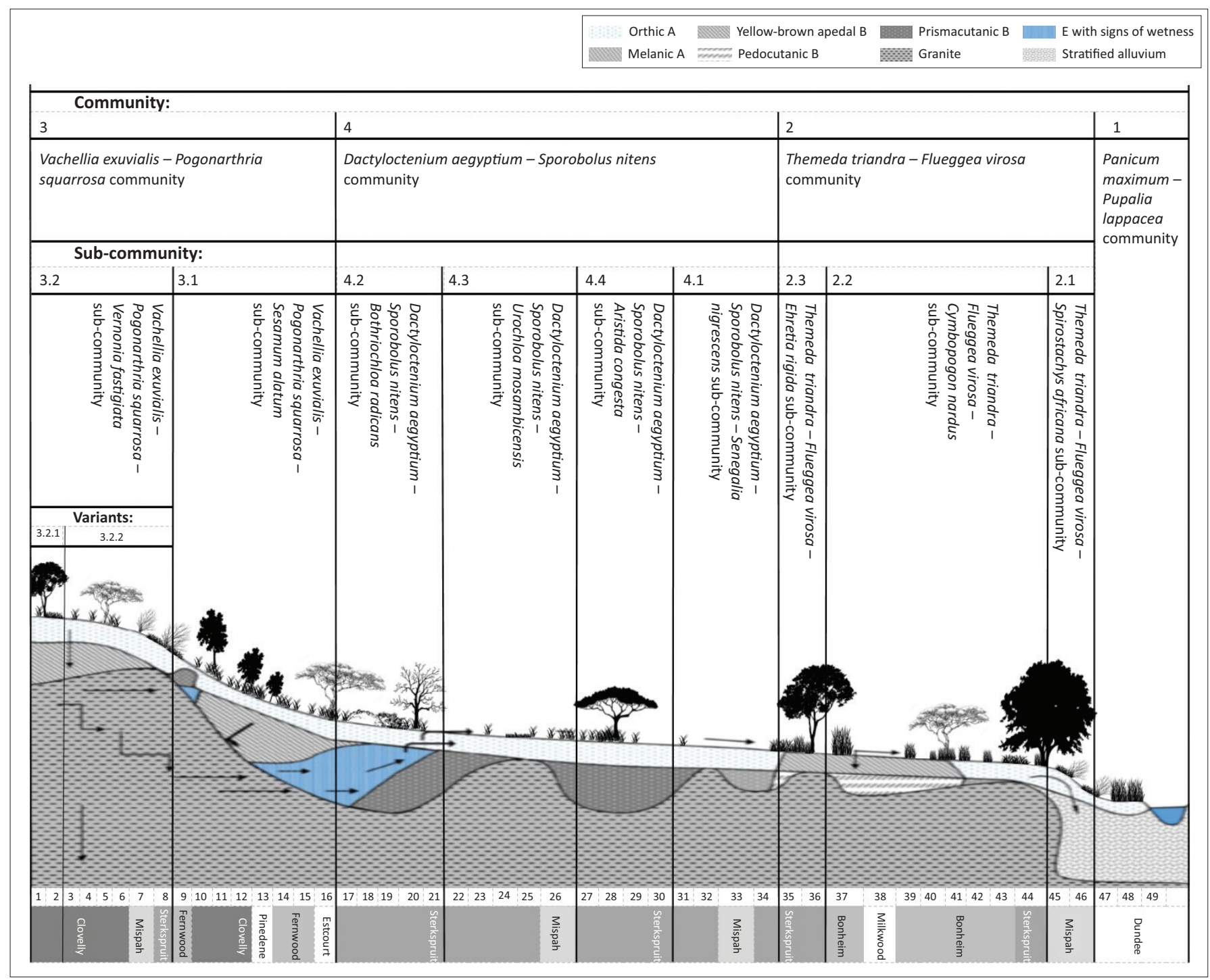

FIGURE 2: Plant community, sub-community and variant distribution aligned with the relevés and soil forms (at the bottom) on which they occur along a hillslope gradient. Arrows indicate the movement of water through the soil sequence (see Bouwer, Le Roux \& Van Tol 2020 for a detailed description). 
TABLE 1: Braun-Blanquet cover abundance scale used - Symbols and associated percentage.

\begin{tabular}{|c|c|c|c|c|c|c|c|c|}
\hline Symbol & $r$ & + & 1 & $2 a$ & $2 b$ & 3 & 4 & 5 \\
\hline$\%$ & $\leq 5 \%$ & $\leq 5 \%$ & $\leq 5 \%$ & $5 \%-12.5 \%$ & $12.5 \%-25 \%$ & $25 \%-50 \%$ & $50 \%-75 \%$ & $\geq 75 \%$ \\
\hline Ground cover & (1-3 individuals) & (few individuals) & & & & & & \\
\hline
\end{tabular}

All soil samples were examined and analysed independently to determine the soil form and its diagnostic horizons using the Soil Classification Working Group's (1991) classification system. To perform chemical and physical analysis on the soil, modal profiles were sampled at $100 \mathrm{~mm}$ depth intervals, dried, sieved and analysed according to standard methods of The Non-Affiliated Soil Analysis Work Committee (1990). Particle size distribution was determined using the pipette method (Miller \& Miller 1987). Thereafter, soil texture was determined using the texture triangle as indicated in the Soil Classification Working Group (1991). The $\mathrm{pH}\left(\mathrm{H}_{2} \mathrm{O}\right)$ was measured from 1:2.5 solutions. In addition, soluble and exchangeable cations $(\mathrm{Ca}, \mathrm{Mg}, \mathrm{K}$ and $\mathrm{Na}$ ) and cation exchange capacity (CEC) were determined using $\mathrm{NH}_{4} \mathrm{OAc}$ solution (Bouwer et al. 2020).

\section{Classification}

Vegetation data were captured with VegCap (unpublished database tool designed by N. Collins), a Macros-enabled Excel spreadsheet, and imported to JUICE@ (Tichý \& Holt 2006) where a Modified TWINSPAN classification (Roleček et al. 2009) analysis was carried out using the pseudo-species cut level (5) and value of cut levels (0, 5, 25, 50 and 75) parameters. The analysis was constrained to a minimum group size of 3-30 clusters with a maximum of 52 . Division reached an endpoint if dissimilarity went lower than 0.3 based on average Jaccard dissimilarity. The resultant clusters were then arranged within both JUICEC and Excel to form the final vegetation communities. No relevés were omitted from the analysis. Brown et al. (2013) indicated that a minimum of three relevés per syntaxon is needed for classification. There were, however, instances where only two relevés defined sub-communities with significant differences in terms of the vegetation. This was done to understand the change in vegetation composition along the catena. Naming of communities, sub-communities and variants was done according to the guidelines presented in Brown et al. (2013). To obtain diagnostic, constant and dominant species, we made use of the Analysis of Columns of a Synoptic Table in JUICE. The frequency thresholds were set at 75, 60 and 50 for the respective diagnostic, constant and dominant species.

\section{Ordination}

The species and environmental data were imported to CANOCOC (Ter Braak \& Smilauer 2002) to perform a direct unimodal canonical correspondence analysis. The analysis was set to focus scaling on inter-species distances with biplot scaling. A log transformation was implemented on the data sets with no down weighing of rare species. Automatic forward selection and the Monte Carlo Permutation tests were used. Lastly, CanoDraw $@$ was used to create simple ordination plots for the soil and chemical data, respectively, in conjunction with certain selected diagnostic and indicator species. Simple ordination plots were also created for the soil and chemical data, respectively, in conjunction with all sample plots. In both cases, the first, second and third axes were used in different combinations, and the most relevant diagrams are shown in the results and discussion.

\section{Ethical considerations}

Ethical clearance to conduct the study was obtained from the Interfaculty Animal Ethics Committee of University of the Free State (clearance number: UFS-AED2019/0121).

\section{Results}

\section{Classification and visualisation}

Hierarchical classification of the Stevenson-Hamilton Research Supersite data revealed four distinct plant communities, which include nine sub-communities and two variants (Online Appendix 1):

1. Panicum maximum-Pupalia lappacea community

2. Themeda triandra-Flueggea virosa community

2.1. Themeda triandra-Flueggea virosa-Spirostachys africana sub-community

2.2. Themeda triandra-Flueggea virosa-Cymbopogon nardus sub-community

2.3. Themeda triandra-Flueggea virosa-Ehretia rigida sub-community

3. Vachellia exuvialis-Pogonarthria squarrosa community

3.1. Vachellia exuvialis-Pogonarthria squarrosa-Sesamum alatum sub-community

3.2. Vachellia exuvialis-Pogonarthria squarrosa-Vernonia fastigiata sub-community

\subsubsection{Terminalia sericea variant}

3.2.2. Grewia flavescens variant

4. Dactyloctenium aegyptium-Sporobolus nitens community 4.1. Dactyloctenium aegyptium-Sporobolus nitens-Senegalia nigrescens sub-community

4.2. Dactyloctenium aegyptium-Sporobolus nitens-Bothriochloa radicans sub-community

4.3. Dactyloctenium aegyptium-Sporobolus nitens-Urochloa mosambicensis sub-community

4.4. Dactyloctenium aegyptium-Sporobolus nitens-Aristida congesta sub-community

These plant communities are distributed from the footslope to the crest with the sodic site indicated as community 4 of the Stevenson-Hamilton Research Supersite (Figure 2). Thus, the communities do not follow the order from the footslope to the crest because of the fact that certain species from the footslope also occur in the crest area. 


\section{Description of plant communities}

Details of the hierarchical vegetation classification are given below with descriptions of each community.

\section{Panicum maximum-Pupalia lappacea community}

Diagnostic species: None

Constant species: Bare soil 100, Bidens bipinnata 75, Panicum maximum 100, Pupalia lappacea 75

Dominant species: Cynodon dactylon 50, Euclea divinorum 25, Gymnosporia glaucophylla 25, Panicum maximum 100, Themeda triandra 25

This community is located in the riparian zone close to the drainage line of the hillside and is found exclusively on Dundee soil forms. The soil profiles are relatively deep $(600 \mathrm{~mm})$ with a sandy loam texture (avg. $\mathrm{pH}_{\mathrm{H}_{2} \mathrm{O}}$ 6.73) and are freely drained; leaching occurs during wet seasons when first-, second- and third-order streams of the study site are in flow. Dundee soil forms are characteristically formed by recent sedimentary deposits from streams and rivers and have a diagnostic stratified alluvium horizon (Fey 2010), which is consistent with the riparian location of this soil within the study area. Community 1 is mainly defined by a grass species Panicum maximum (Species Group U, Online Appendix 1) and the annual Pupalia lappacea (Species Group A, Online Appendix 1). Although P. maximum occurs steadily throughout all the relevés, it has especially high cover abundance values in the relevés of community 1. Bredenkamp (1982) noted in his study that $P$. maximum was mostly found in the shade of trees. The observation is consistent with this P. maximum community situated in the riparian corridor, canopied by large trees. Although not in all relevés, Cynodon dactylon (Species Group A, Online Appendix 1) occurs in few other relevés and has significant cover abundance within community 1 . This is also true for Themeda triandra and Gymnosporia glaucophylla (Species Group G, Online Appendix 1). Among the vegetation in this community, there were also patches of bare soil (Species Group Z, Online Appendix 1).

2. Themeda triandra-Flueggea virosa community

\section{Diagnostic species: None}

Constant species: Bare soil 100, Barleria elegans 67, Dichrostachys cinerea 67, Euclea divinorum 67, Flueggea virosa 83, Grewia hexamita 67, Panicum maximum 83, Senegalia nigrescens 75, Stylosanthes fruticosa 67, Themeda triandra 83, Waltheria indica 75, Ziziphus mucronata 67

Dominant species: Combretum hereroense 8, Eragrostis rigidior 8, Ipomoea species 17 , Panicum maximum 17 , Senegalia nigrescens 8 , Spirostachys africana 8, Themeda triandra 25, Ziziphus mucronata 8

Community 2 is located between the sodic site and the riparian zone on the footslope. This community is dominated by Themeda triandra (Species Group G, Online Appendix 1) and Flueggea virosa (Species Group V, Online Appendix 1). Waltheria indica (Species group N, Online Appendix 1) and Senegalia nigrescens (Kyalangalilwa et al. 2013) (Species Group S, Online Appendix 1) are also prominent species present in this community.
Species such as Stylosanthes fruticosa, Elaeodendron transvaalense and Searsia gueinzii (Species Group B, Online Appendix 1) clearly define this community. Their cover abundance is very low in this community, and they are mostly absent from the other communities studied. This community is similar to the Themeda triandra-Senegalia nigrescens Tall Bushveld communities described by Siebert and Eckhardt (2008) in terms of species composition and the associated Mispah soil form. In terms of species similarity between the studies, prominent species such as Themeda triandra, Euclea divinorum, Waltheria indica and Panicum maximum were present in both studies (Siebert \& Eckhardt 2008).

Community 2 can be divided into the following three subcommunities:

\subsection{Themeda triandra-Flueggea virosa-Spirostachys africana sub- community}

Diagnostic species: Asparagus cooperi 90.3, Carissa bispinosa 100.0, Schotia capitata 75.7, Spirostachys africana 75.7

Constant species: Asparagus cooperi 100, Bare soil 100, Barleria elegans 100, Carissa bispinosa 100, Commelina benghalensis 100, Euclea divinorum 100, Ocimum americanum 100, Panicum maximum 100, Schotia capitata 100, Spirostachys africana 100, Stylosanthes fruticosa 100

Dominant species: Spirostachys africana 50

Sub-community 2.1 is present on the boundary of the riparian zone and occurs exclusively on the Mispah soil form. The soil profiles are relatively shallow (100-200 mm) and consist mainly of sandy clay loam soil, indicative of good drainage (Soil Classification Working Group 1991) and the possible onset of salt accumulation (avg. $\mathrm{pH}_{\mathrm{H} 2 \mathrm{O}}$ 6.56). Mispah soil forms are relatively youthful because of their close relationship with the parent material, often occurring on diagnostically hard rock (Fey 2010) as is consistent with the shallow depths recorded for these relevés.

This sub-community is clearly defined by its position as a transitory zone between the riparian zone and lower footslope of sub-communities 2.2 and 2.3 (Figure 2).

The high cover abundance recorded for Spirostachys africana (Species Group C, Online Appendix 1) does not occur elsewhere along the transect, except for a single occurrence on the sodic site (community 4). Similarly, Carissa bispinosa, Schotia capitata and Asparagus cooperi (Species Group C, Online Appendix 1) occur in this sub-community albeit with low cover abundance and are almost absent or show a very low cover abundance in other communities and sub-communities in this study. The species from Species Group C are thus all regarded as diagnostic species which indicate the uniqueness of these species to this sub-community. When compared to the study by Siebert and Eckhardt (2008), their sub-community with the strong presence of Spirostachys africana can only be compared to the woodland and scrub vegetation found on stream and riverbanks of this study. However, there is no correspondence between species found in Siebert and 
Eckhardt's sub-communities and those of this study. This might be because of the fact that Nkhuhlu is bordered by a perennial river, whereas the Stevenson-Hamilton Research Supersite is not. Thus, at the latter site, the vegetation is dominated more by dry upland species than wet riparian species as indicated by Siebert and Eckhardt (2008).

2.2. Themeda triandra-Flueggea virosa-Cymbopogon nardus subcommunity

Diagnostic species: Cymbopogon nardus 85.4, Hibiscus vitifolius 80.4, Ipomoea species 85.4

Constant species: Bare soil 100, Barleria elegans 75, Cymbopogon nardus 75, Dichrostachys cinerea 88, Flueggea virosa 88, Grewia hexamita 88, Hermannia modesta 62, Hibiscus vitifolius 88, Ipomoea species 75, Panicum maximum 75, Senegalia nigrescens 75 , Themeda triandra 88, Tragia okanyua 62, Vachellia nilotica 75, Waltheria indica 75, Ziziphus mucronata 75

Dominant species: Combretum hereroense 12, Ipomoea species 25, Panicum maximum 25, Senegalia nigrescens 12, Themeda triandra 12, Ziziphus mucronata 12

Sub-community 2.2 is located in the middle of the footslope between the riparian zone and the sodic site and occurs predominantly on Bonheim soil forms. Soil profiles are mostly shallow (381 mm) loam soil, which suggests poorer drainage and increased water retention (avg. $\mathrm{pH}_{\mathrm{H} 2 \mathrm{O}}$ 6.21). Bonheim soil forms are typically dark with structured melanic A and pedocutanic B diagnostic horizons. Often found in semi-arid regions, the soil forms tend to support sweet grazing lawns that are frequented by herbivores (Fey 2010; Moxley 2013).

This sub-community is distinguished by the presence of diagnostic species such as Cymbopogon nardus, Hibiscus vitifolius and Ipomoea species (Species Group D, Online Appendix 1) where some species have high cover abundance values and others low cover abundance values. In contrast, the study by Siebert and Eckhardt (2008) found that Combretum hereroense occurred in most of the vegetation found on the hillslope except next to the river. However, on the transect along the Stevenson-Hamilton Research Supersite, C. hereroense was mostly restricted to the footslope of the valley. Bredenkamp (1982) also indicated that various Combretum species (C. apiculatum, C. zeyheri and C. collinum subsp. zuluense) occur in significant numbers on granitic geological formations in the western parts of KNP, and these species were not that prominent at the StevensonHamilton Research Supersite. Other species that contribute towards defining this sub-community include: Lippia javanica, Philenoptera violacea, Tragia okanyua, Lantana rugosa, Hypoestes forskaolii, Ipomoea oblongata, Panicum coloratum, Gossypium herbaceum, Convolvulus species and Barleria oxyphylla (Species Group D, Online Appendix 1).

2.3.Themeda triandra-Flueggea virosa-Ehretia rigida subcommunity

Diagnostic species: Ehretia rigida 93.6

Constant species: Aristida congesta 100, Aristida meridionalis 100, Bare soil 100, Diospyros mespiliformis 100, Ehretia rigida
100, Eragrostis rigidior 100, Euclea divinorum 100, Flueggea virosa 100, Gymnosporia glaucophylla 100, Kyphocarpa angustifolia 100, Litogyne gariepina 100, Ocimum americanum 100, Panicum maximum 100, Searsia gueinzii 100, Senegalia nigrescens 100, Stylosanthes fruticosa 100, Themeda triandra 100, Urochloa mosambicensis 100, Waltheria indica 100, Ziziphus mucronata 100

Dominant species: Eragrostis rigidior 50, Themeda triandra 100

Sub-community 2.3 is located on the boundary of the lower end of the sodic site and occurs exclusively on the Sterkspruit soil form (Soil Classification Working Group 1991). Sterkspruit soil profiles are relatively shallow $(100 \mathrm{~mm})$ sandy clay loam soil (avg. $\mathrm{pH}_{\mathrm{H}_{2} \mathrm{O}} 6.44$ ), suggesting better water retention, but decreased infiltration. The Sterkspruit soil form is characterised by increased clay content in the prismacutanic B horizon because of illuviation which can result in impeded water movement and root growth, thus diminishing vegetation cover. Furthermore, the soil texture may often lead to crusting and a high degree of erosion (Fey 2010).

This sub-community represents a sharp ecological transition from the open grazing lawns of the sodic site to the bushy vegetation associated with the riparian zone and footslopes. The transition of soil forms - from mostly Bonheim soils in sub-community 2.2 to Sterkspruit soils in sub-community 2.3 (Figure 2) - further supports the difference in ecological parameters for this sub-community.

The diagnostic species for sub-community 2.3 is Ehretia rigida (Species Group F, Online Appendix 1). Although this species has very low cover abundance values, it only occurs in this sub-community and nowhere else in the study area. Diospyros mespiliformis (Species Group F, Online Appendix 1) also define this sub-community, however, does occur in other communities found in the area of study. There are no comparable plant associations in the studies conducted by Siebert and Eckhardt (2008).

3. Vachellia exuvialis-Pogonarthria squarrosa community

Diagnostic species: Vachellia exuvialis 83.4, Pogonarthria squarrosa 91.7, Sporobolus pyramidalis 77.0, Tricholaena monachne 78.9

Constant species: Vachellia exuvialis 81, Aristida congesta 81, Bare soil 94, Bidens bipinnata 69, Combretum apiculatum 69, Combretum zeyheri 62, Digitaria eriantha 75, Kyphocarpa angustifolia 75, Melhania acuminata 88, Panicum maximum 81, Perotis patens 62, Pogonarthria squarrosa 88, Sporobolus pyramidalis 75, Tricholaena monachne 69

Dominant species: Bothriochloa radicans 6, Combretum apiculatum 12, Combretum zeyheri 12, Digitaria eriantha 6, Eragrostis rigidior 19, Panicum maximum 6, Pogonarthria squarrosa 6, Sporobolus pyramidalis 19

Community 3 is located on the crest zone and upslope beyond the sodic site. The Clovelly soil form is prevalent in this community, but the soil forms Pinedene, Fernwood and Estcourt also occur. This community is defined by species 
from Species Group H (Online Appendix 1), with Vachellia exuvialis and Pogonarthria squarrosa being the diagnostic species. In the study by Siebert and Eckhardt (2008), the Enneapogon scoparius-Combretum apiculatum Dry Mixed Savanna community contains species similar to the ones found in this community even though diagnostic species differ between the studies. Significant species for community identification that are shared among these two communities include Combretum apiculatum, Vachellia exuvialis and Pogonarthria squarrosa. Community 3 can be divided into two sub-communities and two variants.

3.1. Vachellia exuvialis-Pogonarthria squarrosa-Sesamum alatum sub-community

Diagnostic species: Sesamum alatum 77.5

Constant species: Vachellia exuvialis 62, Agathisanthemum bojeri 62, Aristida congesta 88, Aristida meridionalis 88, Bare soil 100, Bidens bipinnata 62, Combretum apiculatum 62, Combretum zeyheri 62, Digitaria eriantha 75, Eragrostis rigidior 75, Grewia flavescens 62, Indigofera filipes 75, Kyphocarpa angustifolia 75, Melhania acuminata 75, Panicum maximum 88, Perotis patens 62, Pogonarthria squarrosa 88 , Senegalia nigrescens 62 , Sesamum alatum 62, Sporobolus pyramidalis 62, Tricholaena monachne 62, Waltheria indica 75

Dominant species: Combretum apiculatum 25, Combretum zeyheri 12, Eragrostis rigidior 25, Pogonarthria squarrosa 12

Sub-community 3.1 occurs on both Fernwood and Clovelly soil forms. The Fernwood soil profiles are of intermediate depth $(533 \mathrm{~mm})$ and consist of loamy sand (avg. $\mathrm{pH}_{\mathrm{H} 2 \mathrm{O}}$ 5.95). Fernwood soil forms characteristically have a diagnostic coarse-sand horizon with no clear structure or stratification and have a loose consistency (Fey 2010). The Clovelly soil profiles are deep $(620 \mathrm{~mm})$ with a loam sandy texture (avg. $\mathrm{pH}_{\mathrm{H} 2 \mathrm{O}}$ 6.2). This soil form characteristically has a yellow to brown apedal $\mathrm{B}$ horizon because of iron oxides that accumulate through weathering (Fey 2010).

Species Group I (Online Appendix 1) defines the subcommunity. The diagnostic species in the group, Sesamum alatum, is restricted to this sub-community and does not occur anywhere else in the area of study. Other species with a high occurrence in this sub-community are constant species such as Aristida congesta (Species Group Q, Online Appendix 1), Aristida meridionalis (Species Group R, Online Appendix 1) and also several bare soil patches (Species Group Z, Online Appendix 1) (Janecke, 2020). Other species in this sub-community include: Eragrostis rigidior, E. superba, Indigofera filipes, Cissus cornifolia, Balanites maughamii, Mundulea sericea, Dipcadi gracillimum, Cyperus indecorus, Hibiscus schinzii, Rhynchosia caribaea, E. gummiflua, Cymbopogon pospischilii, Chamaecrista mimosoides, Bulbostylis hispidula and B. burchellii (Species Group I, Online Appendix 1).

Gertenbach (1986) worked on a landscape scale in terms of vegetation classification and described the Senegalia nigrescens/Combretum apiculatum association as Thickets along the Sabie and Crocodile Rivers. In contrast to his study, these species did not dominate the vegetation but were present as components of a larger community.
3.2. Vachellia exuvialis-Pogonarthria squarrosa-Vernonia fastigiata sub-community

Diagnostic species: Chamaecrista absus 75.6, Vernonia fastigiata 80.4

Constant species: Vachellia exuvialis 100, Aristida congesta 75, Aristida stipitata 62, Bare soil 88, Bidens bipinnata 75, Chamaecrista absus 88, Combretum apiculatum 75, Combretum zeyheri 62, Digitaria eriantha 75, Grewia bicolor 75, Heteropogon contortus 62, Justicia protracta 62, Kyphocarpa angustifolia 75, Melhania acuminata 100, Melinis repens 62, Panicum maximum 75, Perotis patens 62, Pogonarthria squarrosa 88, Rhynchosia totta 88, Sporobolus pyramidalis 88, Terminalia sericea 75, Tricholaena monachne 75, Trichoneura grandiglumis 75, Vernonia fastigiata 88

Dominant species: Bothriochloa radicans 12, Combretum zeyheri 12, Digitaria eriantha 12, Eragrostis rigidior 12, Panicum maximum 12, Sporobolus pyramidalis 38

Sub-community 3.2 is located on the crest of the hillslope and occurs mostly on the Clovelly soil form, with single occurrences of the soil forms Mispah and Sterkspruit. The Clovelly soil profiles are deep $(616 \mathrm{~mm})$ and consist of coarse loamy sand (avg. $\mathrm{pH}_{\mathrm{H} 2 \mathrm{O}}$ 6.08).

The diagnostic species unique to this sub-community are Vernonia fastigiata and Chamaecrista absus (Species Group J, Online Appendix 1). These species also occur in other subcommunities but with very low cover abundance values. The research of Siebert and Eckhardt (2008) only had different Vernonia species present in different communities; however, none, which were similar to the combination of diagnostic species, were found in this study. Other species that also define this sub-community include: Heteropogon contortus, Rhynchosia totta, Melinis repens, Justicia protracta, Setaria sphacelata, Jatropha zeyheri, Heliotropium ciliatum, Kyllinga alba and Vangueria infausta (Species Group J, Online Appendix 1).

Sub-community 3.2 encompasses two variants. The Terminalia sericea Variant (3.2.1) contains the following species: Jatropha zeyheri, Heliotropium ciliatum, Kyllinga alba, Vangueria infausta, Aptosimum lineare, Rhigozum zambesiacum and Setaria megaphylla, whereas the Grewia flavescens Variant (3.2.2) contains most prominently Sclerocarya birrea.

4. Dactyloctenium aegyptium-Sporobolus nitens community

Diagnostic species: Chloris virgata 86.9, Dactyloctenium aegyptium 83.1, Schkuhria pinnata 87.8, Sporobolus nitens 81.5

Constant species: Bare soil 94, Chloris virgata 89,Dactyloctenium aegyptium 89, Indigofera tinctoria 61, Kyphocarpa angustifolia 78, Schkuhria pinnata 100, Sporobolus nitens 94, Urochloa mosambicensis 78

Dominant species: Bare soil 6, Dactyloctenium aegyptium 11, Schkuhria pinnata 11, Sporobolus nitens 44, Vachellia nilotica 6

Community 4 is located on the lower-midslope sodic site and occurs almost exclusively on the Sterkspruit soil form, with only two instances of the Mispah soil form recorded. This community is defined by species from Species Group N 
(Online Appendix 1) where the grasses Dactyloctenium aegyptium and Sporobolus nitens have high cover abundance values. Within this community, there are also various bare soil patches (Species Group Y, Online Appendix 1) (Janecke, 2020). Other species that are prominent in this community include Schkuhria pinnata, Chloris virgata, Vachellia nilotica, Indigofera tinctoria, Geigeria burkei, Justicia flava, Ocimum americanum and Cyperus austro-africanus (Species Group N, Online Appendix 1).

Siebert and Eckhardt (2008) also found a sodic site at the Nkhuhlu study area. The Sporobolus nitens-Euclea divinorum Dry Sodic Savanna community indicated high cover abundance of the grass Sporobolus nitens which is similar to that of this study. Furthermore, they found several tree species at their site which is probably the reason for the Dry Sodic Savanna designation. However, in this study most of the woody species, if present at all, were small shrubs. The sodic site of this study was relatively open and mostly covered by grasses and forbs. In contrast to the study by Siebert and Eckhardt (2008) where only two sub-communities were identified, this study identified four different sub-communities.

4.1.Dactyloctenium aegyptium-Sporobolus nitens-Senegalia nigrescens sub-community

Diagnostic species: None

Constant species: Aristida congesta 100, Bare soil 100, Chloris virgata 80, Dactyloctenium aegyptium 100, Digitaria eriantha 80, Indigofera tinctoria 80, Kyphocarpa angustifolia 100, Ocimum americanum 100, Schkuhria pinnata 100, Senegalia nigrescens 80, Sporobolus nitens 80, Urochloa mosambicensis 80

Dominant species: None

Sub-community 4.1 occurs mostly on the Sterkspruit soil from. The soil profile proved to be of intermediate depth (200-500 mm) and consisted on average of coarse sandy loam soil (avg. $\mathrm{pH}_{\mathrm{H} 2 \mathrm{O}}$ 6.20).

This sub-community is defined by Ctenium concinnum, Eragrostis biflora, Ocimum filamentosum and Achyranthes aspera (Species Group O, Online Appendix 1). These species mostly occur in this sub-community; however, there are instances where they are present in other sub-communities but with very low cover abundance values. Senegalia nigrescens (Species Group R, Online Appendix 1) is also present in this sub-community and absent from most of the other sub-communities in community 4 .

4.2.Dactyloctenium aegyptium-Sporobolus nitens-Bothriochloa radicans sub-community

Diagnostic species: None

Constant species: Bare soil 83 , Bothriochloa radicans 67, Chloris virgata 100, Dactyloctenium aegyptium 83, Justicia flava 83, Kyphocarpa angustifolia 83, Melhania acuminata 67, Schkuhria pinnata 100, Solanum panduriforme 83, Sporobolus nitens 100, Urochloa mosambicensis 100

Dominant species: Dactyloctenium aegyptium 17, Sporobolus nitens 83, Vachellia nilotica 17
Sub-community 4.2 occurs exclusively on the Sterkspruit soil form. The soil profile remained shallow $(250 \mathrm{~mm})$ and consisted on average of coarse sandy loam soil (avg. $\mathrm{pH}_{\mathrm{H} 2 \mathrm{O}} 6.24$ ).

There are few other species besides B. radicans (Species Group $\mathrm{S}$, Online Appendix 1) that define this sub-community. However, from Online Appendix 1, it can be seen that species from Species Groups O, P, Q, R and V are totally or mostly absent from this sub-community.

4.3.Dactyloctenium aegyptium-Sporobolus nitens-Urochloa mosambicensis sub-community

Diagnostic species: None

Constant species: Bare soil 100, Blepharis integrifolia 100, Chloris virgata 100, Dactyloctenium aegyptium 75, Litogyne gariepina 75, Schkuhria pinnata 100, Sporobolus nitens 100, Urochloa mosambicensis 75

Dominant species: Schkuhria pinnata 50, Sporobolus nitens 50

Sub-community 4.3 occurs exclusively on the Sterkspruit soil form, with the exception of one occurrence of the Mispah soil form. The soil profiles remained shallow $(230 \mathrm{~mm})$ and consisted on average of coarse sandy loam soil (avg. $\mathrm{pH}_{\mathrm{H} 2 \mathrm{O}} 6.38$ ).

This sub-community is defined by the presence of: Blepharis integrifolia, Alternanthera pungens, Litogyne gariepina and Portulaca kermesina (Species Group V, Online Appendix 1). Although Urochloa mosambicensis is present in most of the relevés within community 4 , it has the highest cover abundance in this subcommunity. This sub-community can further be defined by the absence of species from Species Groups $\mathrm{O}, \mathrm{P}, \mathrm{Q}, \mathrm{R}, \mathrm{S}$ and $\mathrm{T}$ (Online Appendix 1).

4.4.Dactyloctenium aegyptium-Sporobolus nitens-Aristida congesta sub-community

Diagnostic species: None

Constant species: Aristida congesta 67, Bare soil 100, Chloris virgata 67, Dactyloctenium aegyptium 100, Geigeria burkei 67, Indigofera tinctoria 67, Kyphocarpa angustifolia 67, Ocimum americanum 67, Schkuhria pinnata 100, Sporobolus nitens 100, Vachellia nilotica 100

Dominant species: Bare soil 33, Dactyloctenium aegyptium 33, Sporobolus nitens 33

Sub-community 4.4 occurs exclusively on the Sterkspruit soil form. The soil profile remained shallow $(180 \mathrm{~mm})$ and consisted on average of coarse sandy loam soil (avg. $\mathrm{pH}_{\mathrm{H} 2 \mathrm{O}} 6.43$ ).

There are few other species besides Aristida congesta that define this sub-community. This sub-community is mostly defined by the absence of species that define other subcommunities in community 4 .

\section{Ordination of plant communities and selected environmental variables}

The same species used by Bredenkamp (1982) are depicted in Figure 3 (shown by black outlined boxes) in relation to soil forms identified along the hillslope. Distinct relationships are 
shown between species and textural soil properties where certain species are related to a certain soil textural class and a specific soil form. Vachellia exuvialis is associated with coarse, deep sandy soils of the Clovelly form found within the crest zone (Sub-community 3.1) (Species Group H, Online Appendix 1). Panicum maximum is more likely to be associated (higher cover abundance values [Online Appendix 1]) with the Dundee soil form found only in the riparian zone of community 1: Panicum maximum-Pupalia lappacea community (Species Group U, Online Appendix 1). Themeda triandra is shown as equidistant from two environmental variables: soil form and increased clay content. From a catenary perspective, the position of community 2: Themeda triandra-Flueggea virosa supports this relationship. Situated downhill from the sodic site, which acts as a source of clay particles, relevés 35-44 show an increased average clay content (Figure 4) and alignment with the Bonheim soil form (Figure 2).

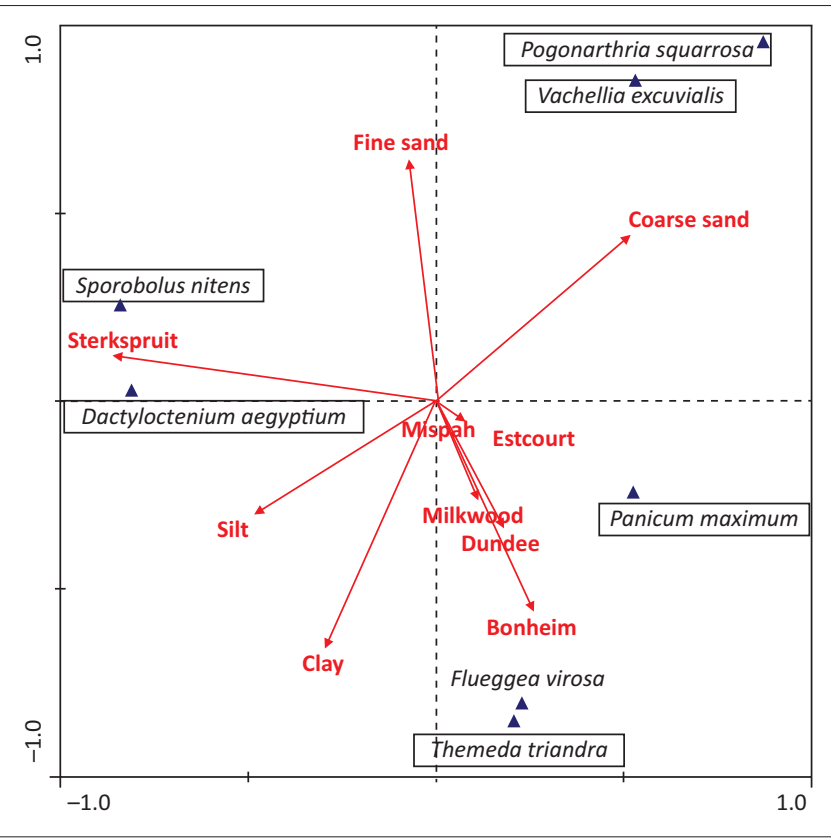

FIGURE 3: Simple ordination diagram of the canonical correspondence analysis (first and second axes) showing the relationships between selected species' cover abundance, soil texture and soil forms. The eigenvalues of the respective axes were 0.642 for axis 1 and 0.523 for axis 2 .
The relationship between selected species and soil chemical properties (The Non-Affiliated Soil Analysis Work Committee 1990) is visualised along the first and third axes in Figure 5. Although the majority of species are grouped to the left of the vertical axis without pronounced associations with chemical soil properties, there are very strong correlations between cations found at the sodic site and the species that occupy this habitat (present on the right of the vertical axis). The grouping of both exchangeable (ions that can be taken up by the plants) and soluble (ions that can be leached out by water) $\mathrm{Na}, \mathrm{K}$ and $\mathrm{Mg}$ with species representative of the sodic site community (community 4: Dactyloctenium aegyptiumSporobolus nitens community) is congruent with the catenary premise that lower midslope sodic sites act as sinks for dissolved particles and salts.

\section{Conclusion}

This study is the first in KNP to directly link the hydropedological conditions of a catena to the distribution of plant communities along the gradient of a granitic supersite. Sharp ecotones in the vegetation can be attributed to the differences in soil texture, hydropedological conditions and chemical properties of soil. The classification of vegetation

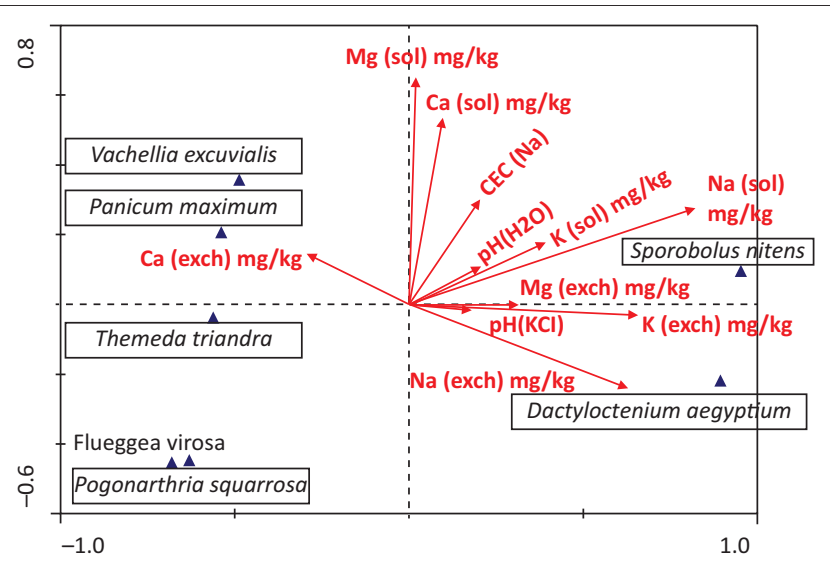

FIGURE 5: Simple ordination diagram of the canonical correspondence analysis (first and third axes) showing the relationships between selected species' cover abundance and soil chemical properties. The eigenvalues of the respective axes were 0.659 for axis 1 and 0.100 for axis 3 .

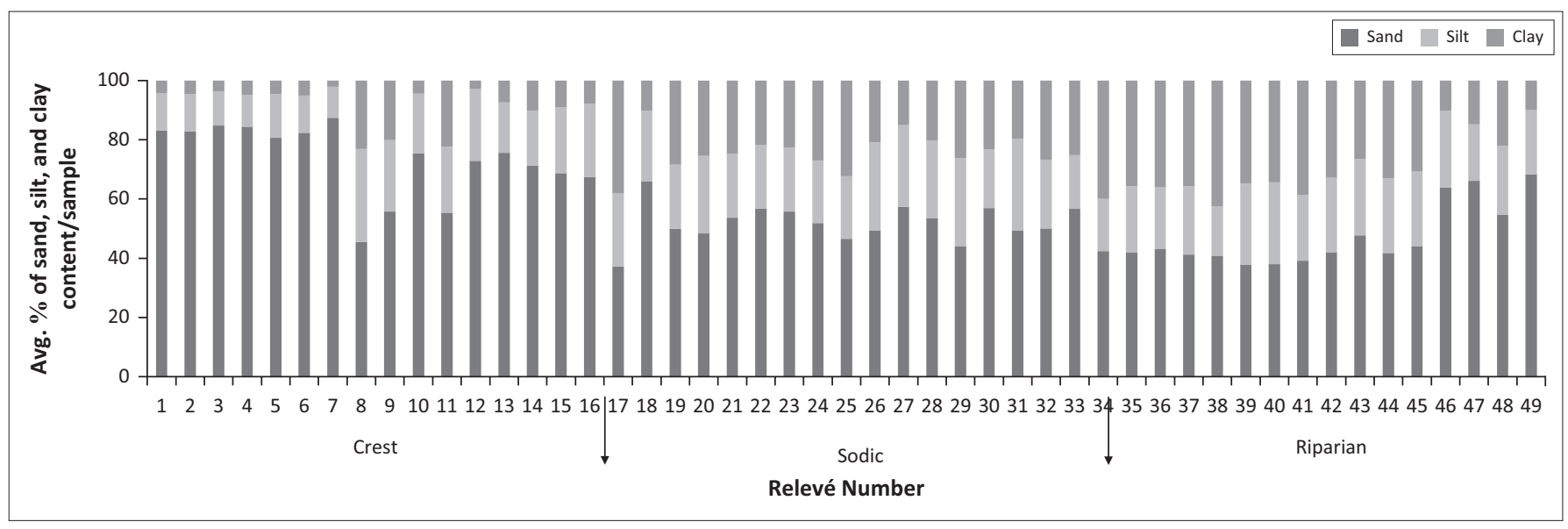

FIGURE 4: Sand, silt and clay content per soil sample collected for each relevé along the study transect. 
communities and the spatial alignment thereof with soil forms and their physical and chemical properties, in this study, again confirmed the close association between fine-scaled plant communities and the individual soil forms on which they occur. The correlation of the abiotic (soil type) and biotic (plant community) parameters that define plant abundance and distribution within this ecosystem is indicative of the interdependency of different ecosystem components on landscape heterogeneity. The results of this study indicate clear differences between plant communities along a catena. These differences can be ascribed to various ecological drivers of which soil seems to play an important role. As a result, the heterogeneity and species composition as well as suitability for various animal species changes along the catena and probably contributes to ecosystem resilience.

\section{Acknowledgements}

The authors thank the South African National Parks for providing them with access to the research sites within Kruger National Park. They are grateful to the field rangers who accompanied them during the surveys. They also thank Louis Scott and Leslie Brown for suggestions on the writing of the article.

\section{Competing interests}

The authors declare that they have no financial or personal relationships that may have inappropriately influenced them in writing this article.

\section{Authors' contributions}

E.J.T. and P.J.d.P. were responsible for the fieldwork, data collection during field surveys, and data analysis and interpretation. A.C.v.A. contributed towards the analysis and interpretation of the plant communities. All authors contributed to the writing of the article.

\section{Funding information}

The authors are grateful to the University of the Free State (UFS) Strategic Research Fund for partially funding this multidisciplinary research.

\section{Data availability}

Data from all research done within Kruger National Park is placed within the SANParks repository (not for free, open access).

\section{Disclaimer}

The views and opinions expressed in this article are those of the authors and do not necessarily reflect the official policy or position of any affiliated agency of the authors.

\section{References}

Alard, G.F., 2009, 'A comparison of grass production and utilization in sodic and crest patches on a semi-arid granitic savanna catena in the southern Kruger National Park, South Africa', MSc thesis, Faculty of Science, University of the Witwatersrand.
Barton, J.M., Bristow, J.W. \& Venter, F.J., 1986, 'A summary of the Precambrian Granitoid rocks of the Kruger National Park', Koedoe 29(1), 39-44. https://doi. org/10.4102/koedoe.v29i1.518

Bouwer, D., Le Roux, P.A.L. \& Van Tol, J., 2020, 'Identification of hydropedological flowpaths in Stevenson-Hamilton catena from soil morphological, chemical and hydraulic properties', Koedoe 62(2), a1584. https://doi.org/10.4102/koedoe. v62i2.1584

Brady, N.C. \& Weil, R.R., 2002, The nature and properties of soils, 13th edn., Prentice Hall, Upper Saddle River, NJ.

Bredenkamp, G.J, 1982, "n Plantekologiese studie van die Manyeleti-Wildtuin', PhD thesis, Departement Plantkunde, University of Pretoria.

Brown, L.R., Du Preez, P.J., Bezuidenhoudt, H., Bredenkamp, G.J, Mostert, T.H.C. \& Collins, N.B., 2013, 'Guidelines for phytosociological classifications and descriptions of vegetation in southern Africa', Koedoe 55(1), Art. \#1103, 10. https://doi.org/10.4102/ koedoe.v55i1.1103

Conacher, A.J. \& Dalrymple, J.B., 1977, 'The nine unit based landsurface model. An approach to pedogeomorphic research', Geoderma 18(1-2), 1-154. https://doi. org/10.1016/0016-7061(77)90087-8

Fey, M., 2010, Soils of South Africa: Their distribution, properties, classification, genesis, use and environmental significance, Cambridge University Press, Cape Town.

Gertenbach, W.P.D., 1986, 'Landscapes of the Kruger National Park', Koedoe 26(9), 9-121. https://doi.org/10.4102/koedoe.v26i1.591

Hugget, R.J., 2007, Fundamentals of Geomorphology, 2nd edn., Routledge Taylor \& Francis Group, New York, NY.

Janecke, B.B., 2020, 'Vegetation structure and spatial heterogeneity in the Granite Supersite, Kruger National Park', Koedoe 62(2), a1591. https://doi.org/10.4102/ koedoe.v62i2.1591.

Kent, M., 2012, Vegetation description and data analysis: A practical approach, 2nd edn., Wiley-Blackwell Publishers, West Sussex.

Kent, M. \& Coker, C., 1992, Vegetation description and analysis: A practical approach, Bellhaven Press, West Sussex.

Khomo, L.M., Hartshorn, A.S., Rogers, K.H. \& Chadwick, O.A., 2011, 'Impact of rainfal and topography on the distribution of clays and major cations in granitic catenas of southern Africa', Catena 87(1), 119-128. https://doi.org/10.1016/j. catena.2011.05.017

Khomo, L.M. \& Rogers, K.H., 2005, 'Proposed mechanism for the origin of sodic patches in Kruger National Park, South Africa', African Journal of Ecology 43(1), 29-34. https://doi.org/10.1111/j.1365-2028.2004.00532.x

Kruger, A.C., Makamo, L.B. \& Shongwe, S., 2002, 'An analysis of Skukuza climate data', Koedoe 45(1), 1-7. https://doi.org/10.4102/koedoe.v45i1.16

Kyalangalilwa, B., Boatwright, J.S., Daru, B.H., Maurin, O. \& Van der Bank, M., 2013, 'Phylogenetic position and revised classification of Acacia s.l. (Fabaceae: Mimosoideae) in Africa, including new combinations in Vachellia and Senegalia', Botanical Journal of the Linnean Society 172(4), 500-523.

McCarthy, T. \& Rubidge, B., 2005, The story of earth \& life: A southern African perspective on a 4.6-billion-year journey, Struik Nature, Cape Town.

McNaughton, S.J., 1988, 'Mineral nutrition and spatial concentrations of African ungulates, Nature 334, 343-345. https://doi.org/10.1038/334343a0

Miller, W.P. \& Miller, D.M., 1987, 'A micro-pipette method for soil mechanical analysis', Communications in Soil Science and Plant Analysis 18(1), 1-15. https://doi. org/10.1080/00103628709367799

Moxley, C., 2013, 'Characterization of biotic and abiotic sodic lawns of the Kruger National Park using the framework of the positive feedback loop', Honours thesis, Department of Biological Sciences, University of Cape Town.

Mucina, L. \& Rutherford, M.C. (eds.), 2006, The vegetation of South Africa, Lesotho and Swaziland, Strelizia 19, South African National Biodiversity Institute, Pretoria.

Naidoo, L., Cho, M.A., Mathieu, R. \& Asner, G., 2012, 'Classification of savanna tree species, in the Greater Kruger National Park region, by integrating hyperspectral and LiDAR data in a Random Forest data mining environment', ISPRS Journal of Photogrammetry and Remote Sensing 69, 167-179. https://doi.org/10.1016/j. isprsjprs.2012.03.005

Naidu, R. \& Rengasamy, P., 1993, 'Ion interactions and constraints to plant nutrition in Australian sodic soil', Australian Journal of Soil Research 31(6), 801-819. https:// doi.org/10.1071/SR9930801

Roleček, J., Lubomír, T., David, Z. \& Chytry, M., 2009, 'Modified TWINSPAN classification in which the hierarchy respects cluster heterogeneity', Journal of Vegetation Science 20(4), 596-602. https://doi.org/10.1111/j.1654-1103.2009.01062.x

Rutherford, M.C. \& Westfall, R.H., 1986, 'Biomes of southern Africa - An objective categorization', Memoirs of the Botanical Survey of South Africa 54, 1-98.

Scholes, R.J., Bond, W.J. \& Eckhardt, H.C., 2003, 'Vegetation dynamics in the Kruger Ecosystem', in JT. Du Toit, K.H. Rogers \& H.C. Biggs (eds.), The Kruger experience: Ecology and management of Savanna heterogeneity, pp. 242-262, Island Press, London.

Schutte, I.C., 1974, 'n Geologiese verkenningsopname van die noord-sentrale gedeelte van die Nasionale Krugerwildtuin, Geological Survey, Pretoria.

Siebert, F. \& Eckhardt, H.C., 2008, 'The vegetation and floristics of the Nkhuhlu Enclosures, Kruger National Park', Koedoe 50(1), 126-144. https://doi.org/ 10.4102/koedoe.v50i1.138

Smit, I.P.J., Riddell, E.S., Cullum, C. \& Petersen, R., 2013, 'Kruger National Park research supersites: Establishing long-term research site for cross-disciplinary, multiscaled learning', Koedoe 55(1), Art. \#1107, 7 pages. https://doi.org/10.4102/koedoe. v55i1.1107

Soil Classification Working Group, 1991, Soil classification: A taxonomic system for South Africa, Department of Agricultural Development, Pretoria. 
Ter Braak, C.J.F. \& Smilauer, P., 2002, CANOCO Reference manual and CanoDraw for Windows User's quide: Software for Canonical Community Ordination version 4.5, computer software, Microcomputer Power, Ithaca, NY.

The Non-Affiliated Soil Analysis Work Committee, 1990, Handbook of standard soil testing methods for advisory purposes, Soil Science Society of South Africa, Pretoria.

Tichý, L. \& Holt, J., 2006, JUICE: A program for management, analysis and classification of ecological data, Vegetation Science Group, Masaryk University Brno, Brno.

Van der Maarel, E. \& Franklin, J., 2013, Vegetation ecology, 2nd edn., John Wiley \& Sons, Ltd., West Sussex.
Van Tol, J.J., Van Zijl, G.M., Riddell, E.S. \& Fundisi, D., 2015, 'Application of hydropedological insights in hydrological modelling of the Stevenson-Hamilton Research Supersite, Kruger National Park, South Africa', Water SA 41(4), 525-533. https://doi.org/10.4314/wsa.v41i4.12

Van Zijl, G. \& Le Roux, P., 2014, 'Creating a conceptual hydrological soil response map for the Stevenson Hamilton Research Supersite, Kruger National Park, South Africa', Water SA 40(2), 331-336. https://doi.org/10.4314/wsa.v40i2.15

Venter, F.J., Scholes, R.J. \& Eckhardt, H.C., 2003, 'The abiotic template and its associated vegetation pattern', in J.T. Du Toit, K.H. Rogers \& H.C Biggs (eds.), The Kruger experience: Ecology and management of Savanna heterogeneity, pp. 83129, Island Press, London. 